Volume 4 Number 4 June 2021

\title{
The Role of Guidance Teachers in Optimizing Standards of Child Development Achievement Level in PAUD
}

\author{
Lahmuddin Lubis, Shamsu Nahar, Ima Kurniati Simbolon \\ Universitas Islam Negeri Sumatera Utara \\ imakurniati1968@gmail.com
}

\begin{tabular}{ll}
\hline Article History & Received : Feb 9 $9^{\text {th }} 2021$ \\
& Revision : April 13 2021 \\
& Publication : June $30^{\text {th }} 2021$ \\
\hline
\end{tabular}

\begin{abstract}
This study explores the role of a teacher in optimizing achievement levels and providing guidance to children. The standards to be achieved are Standards of Early Childhood Development Achievement Level (STPPA), Content Standards, Process Standards, Assessment Standards, Educators and Education Personnel Standards, Infrastructure Standards, Management Standards, and Financing Standards. This research uses qualitative research that is descriptive in nature, namely the data collected is generally in the form of words, pictures, the data in question includes interview transcripts, field data notes and other notes. As for the results of his research that overall it has not been maximal in carrying out its role as a teacher in guiding students to achieve growth and development in accordance with the stage of development which includes all aspects of development as contained in the Standards for Child Development Achievement Level (STPPA). The cause of these problems is due to the lack of support in the form of. education and training (diklatdiklat) that are relevant in supporting his knowledge about educating early childhood. In addition, there is still a lack of training activities for teachers in the development of Early Childhood Education (PAUD) so that it continues to be better. Likewise, in establishing cooperation between schools and parents, it is still rare. The implementation of the Child Development Achievement Level Standards (STPPA) in PAUD Tunas Harapan, Patumbak sub-district, Deli Serdang district has not been carried out properly. Learning activities are carried out not using all aspects of development in the Child Development Achievement Level Standards as a reference in achieving children's development. Learning programs tend to be aimed at providing children's cognitive abilities
\end{abstract}

Keyword : Guidance Teachers, Child Development Achievement, PAUD

\section{INTRODUCTION}

Education is part of a country's development program. Therefore education is at the heart of the development of a nation and education is also part of human life as a driver of the nation's progress. Thus the back and forth of a nation is determined by education. Education aims to help individuals become mature and independent, with the understanding that through education humans are able to recognize, understand and apply abilities, 
potential and skills to humans to advance the nation and state (Bakar, 2012). Ulwan (2013) said that the process of advancing the nation and state cannot be separated from the role of educator or teacher. Therefore, it is very important for a qualified and professional teacher to carry out his duties. The field of education has become very interesting, both from the government through the Ministry of Education of the Republic of Indonesia as the highest level of education structure in Indonesia and a smaller community group, namely the family as the lowest level responsible for the education of Indonesian children.

Apriyanti (2017) told The concept of Early Childhood Education (PAUD) is isomorphic, meaning that the PAUD scientific framework is built from interdisciplinary science which is a combination of several disciplines of science, including: psychology, physiology, sociology, children's education, anthropology, humanities, health, and nutrition and neuroscience or science of human brain development (Yulianai Nurani Sujiono, 2009: 10). Based on psychology and pedagogical science, early childhood is the primary period or foundation for the growth and development of children. What children get at an early age, both food, drink, and stimulation from the environment, contributes significantly to the growth and development of the child in that time and the next.

The value of children for parents at least refers to the views, namely: (1) children as the grace of God, (2) children as the trust of God, (3) children as pawns, (4) children as testers of faith, (5) children as a medium of charity, (6) children as provisions of the afterlife, (7) as an element of happiness, (8) as a place of focus in old age, (9) children as a link of ideals. Shafaruddin (2011:10).

Children can be the pride of parents as children grow and develop according to their expectations and in accordance with God's expectations. This way children can be happy when children achieve the hopes of God and their parents. But if the child is poor and poor, because his parents do not fulfill God's mandate or any other reason, the child can cause disaster. Early Childhood Education as the strongest foundation for maintaining national character in the future. The better the quality of early childhood education, the stronger the building of the foundation of intelligence of the nation's children. Conversely, the lower the quality of education at this level is getting weaker the possible character of the nation's children in the future (Hakim, 2011).

The objectives of Early Childhood Education (PAUD) according to Hartati (2017: 157) include: to form a quality child, namely children who grow and develop in accordance with their level of development so as to have optimal readiness in entering basic education and wading into life in adulthood and to help prepare children to achieve learning readiness in the next education. Early Childhood Education (PAUD) is also expected to be able to develop various potentials of children from an early age as preparation for life and can adjust to their environment (Apriyanti, 2017)

Therefore the development of children towards maturity requires guidance from educators and parents. Educators take full responsibility for the optimal development of 
children, from an early age by providing education and guidance that meets all aspects of children's growth and development so that children at an early age are truly ready to receive education at a later age. Achievement of all aspects of early childhood growth and development as contained in the Standard of Child Development Achievement Level (STPPA).

People are increasingly aware of the importance of early childhood education. This is evidenced by the development of formal, informal and non-formal education in early childhood throughout Indonesia, some in the form of day care parks, playgroups or playgrounds, kindergartens and similar early childhood education. The importance of early childhood education requires an approach used in child-centered learning activities. However, one problem lies in the fact that not every parent or educator understands the right way to teach children from an early age.

A teacher as a guide strives in directing and guiding learners in order to discover the various potentials they have, so that learners can achieve and carry out their developmental tasks so that with that ability he can grow and develop as an independent and productive individual. Because the uniqueness of early childhood where each other is not equally good in talent, interests, abilities and so on, then the rhythm of development is also not the same. This difference is what requires a teacher to act as a guide.

If you look at the fact that the number of professional counselors in Indonesia is still relatively limited, then the role of teachers as mentors seems to be important as well as in early childhood education units (PAUD). The absence of professional counselors in schools is certainly an effort to guide students is absolutely necessary. If the school happens to have a professional counselor then the teacher can work with the counselor on how to guide students in school. But if there is none then the guidance activities will be focused on the teacher.

Not everyone understands the basic characteristics of children so it is often wrong in educating children. Especially with the rapid development of information technology and the world of children, many parents are not ready for their children to enter the digital world. If parents ignore this development, then the control of children and the functioning of the family as a social institution will be weakened. Likewise in school education, there are still many educators who do not understand the basic rights of children so they are wrong in educating.

Similarly, with PAUD Tunas Harapan which is one of the PAUDs in Patumbak subdistrict, teachers have not mastered the whole about growth and development and its aspects so as not to be wrong when determining appropriate activities to support the growth and development of their students. Learning activities that take place in PAUD Tunas Harapan are mostly carried out in the classroom and are dynamic, teachers do not have the skills in designing learning programs and the ability to manage learning using learning 
media, this can be seen from teachers who carry out learning activities do not prepare learning planning every day.

Being a teacher is not easy. Teachers are figures and role models of people who can do various things in saving their students, have various skills and abilities, because a teacher is a role model and model of example for students and their environment, become parents in school and can quickly overcome student problems. Therefore, educators in the Early Childhood Education (PAUD) unit must have certain personal quality standards that include pedagogical competence, personality competence, professional competence, and social competence.

This standard of personal quality is not owned by PAUD Tunas Harapan teachers, teachers do not fully master their competence as PAUD teachers in guiding learners to achieve optimal growth and development in accordance with the stage of development. Teachers' still low competence will result in a low-quality generation as well. Teacher competence is the main key in producing a golden generation, because competent teachers will be able to bring a full class atmosphere and excitement and fun. The weak competence possessed by teachers in the early childhood education unit Tunas Harapan is the cause of the lack of optimal role of teachers. Teachers are at the forefront of various efforts to improve the quality of national education, therefore teachers are one of the factors that determine the success or failure of educational quality improvement and innovation efforts in schools. Quality educational services and most of the primary responsibility for realizing these ideals are on the shoulders of teachers.

Furthermore, the quality of educators in the institution of PAUD Tunas Harapan is still many early childhood educators who have not had an S1 background. PAUD Tunas Harapan teacher education qualifications still do not meet the ideal conditions, where there are only a few percent of PAUD teachers who have undergraduate qualifications and most of them are high school graduates / equivalent. PAUD Tunas Harapan teachers who have undergraduate education are actually also not all have educational qualifications relevant to PAUD, which should be educators in PAUD institutions have diplomas S1 PAUD and S1 Psychology as mentioned in the regulation of the Minister of Education and Culture (Mendikbud) RI Number 137 of 2014 on PAUD standards, it is stated that PAUD teachers must be educated undergraduate / equivalent in the field of education relevant to PAUD or Graduated from psychology. While the PAUD companion teacher is at least high school / equivalent and has a PAUD training certificate. Because behind the education of PAUD educators can affect the quality of quality PAUD implementation.

In response to the current PAUD teacher qualification problem, innovation is needed in education and training for PAUD teachers. One of them is by utilizing digital technology. By utilizing this potential, improving the quality of PAUD teachers can occur quickly. To present quality PAUD standards, human resources (HR) are also needed. 
This is supported by research conducted by (Widodo, 2017) in the Scientific Journal of The Vision of Educators and Non-Formal Education Personnel on Teacher Competence in the Development of Early Childhood Gross Motor Skills Based on Academic Qualifications. The results stated that the improvement of the competence of PAUD teachers can not be separated from the improvement of academic qualifications, because high academic qualifications can improve competence. There are still many PAUD teachers who do not meet academic / undergraduate qualifications as non-permanent teachers, so it is financially less likely to continue to the undergraduate level at their own expense.

In addition to the low public awareness of the importance of education at an early age and excessively high public expectations of aspects of children's cognitive abilities cause the direction of early childhood education development today is considered still inappropriate. Dni Age Education (PAUD) is essentially an education that seeks to develop all the potential of children both cognitive, affective and psychomotor potential in ways that are in line with their development, including learning through play. Therefore, efforts to provide proper understanding to the community about the components of early childhood education need to be done.

Early childhood education (PAUD) Tunas Harapan is more pursuing the wishes of the community and parents, such as the child's ability to read, write and count to the maximum, not education that is in accordance with the growth and development of children in various aspects of development as contained in the Standard of Child Development Achievement Level (STPPA) so that in terms of the quality of PAUD Tunas Harapan services are not in accordance with the standards.

With the increasing quantity of PlayGroup institutions and the quality problems of PAUD institutions in Indonesia, in 2013 the Ministry of Education and Culture of the Directorate of Early Childhood Education, Nonformal and informal drafted a Technical Instruction for the Implementation of PlayGroups with reference to Permendiknas No. 58 of 2009. Then Permendiknas was updated with the issuance of Permendiknas No.137 of 2014 regarding the National STANDARD OF PAUD which is further called the PAUD Standard. PAUD standards include Early Childhood Development Achievement Standards (STPPA), Content Standards, Process Standards, Assessment Standards, Educator and Education Personnel Standards, Infrastructure Facilities Standards, Management Standards, Financing Standards.

The above phenomena occur in PAUD Tunas Harapan which is the author's research site. Based on the background of the above problems, the researcher assesses the discussion of the role of guidance teachers in optimizing the Standard of Child Development Achievement Level (STPPA) in PAUD Tunas Harapan Patumbak District Deli Serdang, it needs to be done both through literature studies and author experience. 
Volume 4 Number 4 June 2021

\section{METHOD}

The researchers use qualitative research that is descriptive i.e. the data collected is generally in the form of words, images, data in question including interview transkip, field data records and other records. Bogdan Taylor in Lexy (2002:3) defines qualitative methodology as a research procedure that produces descriptive data as written or spoken words from people and observable behaviors. According to them this approach is directed at the background of the individual holistically. Whereas according to Noeng (1996: 11) qualitative approach, research that is holistic and systematic related as a whole, not focused (research target) or the perpetrator himself who interprets about his actions. In other words, the data gathering tool is the researcher himself.

This qualitative method is used due to several considerations. First, this approach presents directly the nature of the relationship between researchers and informants. Second, this approach presents can describe the problems that occur on the ground. In qualitative research, the data collected is in the form of words, pictures and not numbers. In addition, qualitative research is more concerned with process than results. This is because the relationship of the parts studied will be much clearer when observed in the process. Moleong (2010:9-12). The data analysis used in this study uses qualitative data analysis of interactive models from Miles and Huberman consisting of (a) data reduction, (b) presentation of data, and (c) conclusions, where the process takes place circularly during the study.

\section{RESULTS AND DISCUSSION}

\section{Understanding of PAUD Teachers Shoots Patumbak Subdistrict Expectations on Standards of Child Development Achievement Level (STPPA).}

The National Standard of PAUD is a criterion on the management and implementation of PAUD in all jurisdictions of the Unitary State of the Republic of Indonesia, in accordance with Permendikbud Number. 137 of 2014 in which listed standards for the Level of Achievement of Child Development (STPPA). Furthermore, the Standard of Achievement of Early Childhood Development (STPPA) is a criterion about the ability that will be achieved by children covering all aspects of development, namely aspects of religious and moral values, motor-motor, cognitive, language, social-emotional, and art. In accordance with Permendikbud No. 37 of 2014 which explained that early childhood education is an education aimed at early childhood to stimulate and maximize aspects of its development.

The Head of PAUD Tunas Harapan is known that the understanding of PAUD Tunas Harapan teachers about The Standard of Child Development Achievement Level can be said to be inadequate because only some teachers can understand the Standard of Child Development Achievement Level and some still lack understanding, while the Standard of Child Development Achievement Level is one part of the PAUD standard that must be understood in carrying out the learning process in PAUD. Learning outside the classroom is very important in the early childhood learning process. Learning and teaching methods 
outside the classroom are very powerful in educating children, encouraging them to master various learnings, and improve their achievement compared to other children with classroom learning systems. They are easier to understand than to learn in the classroom. Education outside the classroom aims so that children can adapt to the environment and the environment. Outdoor play is very fun and important for a child's growth and development.

The importance of understanding and using the Standard of Child Development Achievement Level (STPPA) as a reference in designing learning activities in PAUD for each teacher is an accurate instruction on teaching standards to achieve maximum early childhood development at the end of the service. A fundamental understanding of the six aspects of the Standard of Child Development Achievement Level (STPPA) must be interpreted seriously and thoroughly for every teacher of the Early Childhood Education (PAUD) unit. Education at the PAUD unit level that has been understood by PAUD teachers is more emphasized to learning on cognitive aspects. Cognitive aspects become the demands of the guardians of students / parents so that their children have knowledge in terms of reading, writing and counting (calistung) smoothly. Though there are still five other aspects of development that must be taught by every teacher at the PAUD unit level.

There are still a number of teachers who do not understand the Standard Level of Child Development Achievement (STPPA) which is partly due to:

1. There are still teachers who do not have $\mathrm{S} 1$ competency standards.

2. Teachers who have a bachelor's degree are not in accordance with the field of PAUD education.

3. There are teachers who enter alternately (teaching for six months replaced with a new teacher)

4. Limited educational and training activities for PAUD teachers understand the Standard of Child Development Achievement Level (STPPA).

5. The Principal does not get clear information about the Standard Level of Child Development Achievement (STPPA) so is not able to provide education and training to teachers.

6. Limited budget to provide education and training to PAUD teachers in each school.

PAUD trainings from the government through the education office are still very limited and cannot reach all existing PAUD teachers, but independent trainings also exist but because of budget constraints due to the low honor of PAUD teachers so that teachers are unable to follow them at independent costs. While still rarely the principal who wants to facilitate his teacher to follow the training madiri. In addition, there are still teachers who enter alternate, because the teacher's honor is still very low so that there are teachers who go in and out. This often happens in PAUD in the unlike least in PAUD Tunas Harapan. The same thing happens so that the incoming teacher has to start learning again from the beginning. 


\section{Implementation of The Standard of Child Development Achievement Level (STPPA) in learning activities at PAUD Tunas Harapan.}

Implementation of the Standard of Achievement Level of Child Development in question is the application or implementation of the criteria of ability achieved by children in all aspects of development and growth that include aspects of religious and moral values, physical-motor, cognitive, language, social emotional and art in learning activities in PAUD Tunas Harapan patumbak subdistrict. As many teachers as PAUD Tunas Harapan have implemented the Standard of Child Development Achievement Level (STPPA) in daily learning activities only because not all teachers understand the Standard of Child Development Achievement Level (STPPA) then in the preparation of learning teachers do not use learning planning as outlined in the form of a Daily Learning Implementation Plan (RPPH). Every teacher should make a learning plan by preparing a Daily Learning Implementation Plan (RPPH), Rancana Implementation of Weekly Learning (RPPM) and Semester Program (Prosem) as a reference for teachers in carrying out teaching and learning process activities every day.

The learning process will be successful if a teacher is able to understand learning planning well. For that it should be before the learning process is carried out a teacher must design learning. Learning planning is very important in developing the PAUD curriculum. As a professional educator, learning planning is a responsibility in developing all the potential of children. Planning is intended to direct learning in order to run as it should in order to achieve the desired goal.

But there are many records such as teachers who do not make notes about the achievement of children's development during learning activities that take place every day. Though the record is very important, and with the records obtained by the teacher through observations made every day, the teacher will be able to measure the success of learning that has been done. Because learning achievement is a picture of the achievement of growth and development of children based on six aspects of development. Teachers at PAUD Tunas Harapan do not have documented child development achievement documented in the form of daily recordings, weekly recordings and monthly recordings and semester recordings. Reporting of child development that aims to find out the child's development and learning outcomes related to the child's development, through the support delivered to parents at the end of the semester only. Whereas every PAUD teacher should conduct an assessment of early childhood through observations made by noting about the child's attitudes and behavior in certain situations through a portfolio obtained from the collection of child labor results that can describe where the child's skills develop. With an assessment that is not in the form of numbers but a child development report in the form of a description or brief description of the child's development that has been achieved at each meeting. In addition, STPPA (standard level of child development achievement) must be run by every teacher at 
the PAUD unit level. Each teacher makes direct observations of the child's existence as well as the child's development at the time of learning through play. If each teacher performs the observation process well, it will be obtained the development of children to make changes in the improvement of ability at a later stage. Then the teacher must also make correct observations of the child's development. Teachers must have a child's development record/document that is evaluated every day. But in reality all teachers at the unit level PAUD Tunas Harapan do not do the instructions contained in the STPPA.

Understand the existence of PAUD in general at the present time that if STPPA is applied at each level of PAUD units, it will be viewed objectively the success of students. The existence of students having regular developments must have documents for each student. Documents and records are evidence of an official report on child development. When STPPA is applied thoroughly to PAUD units, PAUD throughout Indonesia will give birth to bright children. These brilliant children are children who develop very well when they attend education in PAUD units. The brilliance of PAUD students is based on the progress report reported by the teacher through documents and diaries of each student.

\section{Role of Guidance Teacher in PAUD Tunas Harapan}

One of the teachers in the teaching and learning process is the teacher as a guide. The role of the teacher as a guide is more important, because the presence of teachers in school is to guide learners into capable adult humans. Without teacher guidance, students will have difficulty in dealing with their development. The lack of student affordability leads to more depending on the help of the teacher. Although increasingly mature, the dependence of learners is decreasing (independent).

The guidance teacher referred to by the researchers in this study is a PAUD teacher. PAUD teachers as guidance teachers in accordance with the Minister of National Education Regulation No. 58 of 2009 on Early Childhood Education Standards, mentioned that early childhood educators are professional teachers who are tasked with planning, carrying out the learning process, and assessing the results of education, serta conducting guidance, training and protection of students. PAUD educators are based in various types of services both on formal and non-formal education lines such as kindergarten / RA, KB, TPA and other forms of equality. PAUD educators on the formal education path consist of teachers and pendamping teachers; while PAUD educators on nonformal education pathways consist of teachers, teachers, and caregivers.

PAUD teachers as mentors play an important role in guiding children in exploring the potential of students in accordance with the uniqueness of each child that is different from one child to another. Guidance teachers are required to have a variety of knowledge including knowledge about child development, about body anatomy, psychology, child health problems and most importantly must love children. 
Based on observations made on Thursday, October 24, 2019 at 08.00 wib researchers still found some teachers who teach without using reference and planning properly, by not preparing a Daily Learning Implementation Plan (RPPH). They are teachers of PAUD Tunas Harapan teaching only based on magazines prepared by the school. This is also supported by the results of observations made by researchers on academic documents, namely archives related to preparation in teaching and learning activities in PAUD Tunas Harapan district patumbak TA.2019/2020 that there is no documentation about the Learning Implementation Plan (RPPH) prepared by teachers, of which there are only KTSP stored by the Principal in the office. The teachers have not poured KTSP in the form of RPPH and RPPM to be used as a reference for each teacher's handle in carrying out the teaching and learning process, as outlined in the previous chapter that the professional PAUD teacher is a professional graduate of Bachelor S1 / Diploma IV who is in charge of planning, carrying out the learning process, assessing learning outcomes, conducting guidance, nurturing and protection of students.

The role of Guidance Teachers in PAUD Tunas Harapan district of Patumbak Deli Serdang district is still less than optimal because the teachers in PAUD Tunas Harapan are partly high school education, not yet S1, even if there is S1 but not linear, in addition they also lack knowledge about Early Childhood Education through workshops, follow other relevant trainings, both trainings from very rare and limited services and trainings and trainings on a regular basis. self-sufficient. The difficulty of finding teachers whose linear education is also a problem in addition to the salaries of PAUD teachers who are still very low because of low tuition.

Teachers who do not prepare a Daily Learning Implementation Plan (RPPH) in planning learning activities, he feels that what is taught has touched all six aspects in the STPPA. Likewise, communication with parents is one of the problems. Parents who do not understand learning in PAUD, so ask the teacher to scold their child, even though scolding children is strictly prohibited in PAUD, as well as parents who demand their children to be given homework and teachers ultimately follow the will of parents by providing homework. The incomprehension of parents of students about early childhood education by asking for homework for their children who are then followed by teachers, because teachers who are less able to provide understanding to parents so as to follow what parents want. This is due to the lack of teacher knowledge about early childhood education due to low teacher education or not in accordance with the specified qualifications and is less supported by attending education and training, seminars or learning independently by finding out from other sources about the Standard Level of Child Development Achievement (STPPA).

Schools need to involve parents in the maintenance of PAUD. Parental involvement in the child's learning process and experience in PAUD makes the relationship between parents and schools well established. Through school programs that need to be communicated to parents so that they understand the process and learning of their children as well as the 
responsibility of parents to achieve the goal of developing their child's potential. This is important because the lack of understanding of parents of school programs leads to their low participation in their child's learning process and experience in school. The impression of schools that assume parents fully delegate their child's educational responsibilities to schools is less reasoned when schools fail to establish good relations with parents. Therefore, schools need to provide parents with an understanding of the forms and benefits of their involvement in their child's learning process and experience in school.

As a result of the lack of understanding of teachers in the management of the implementation of education for early childhood can make the learning process in PAUD run less optimally. The existence of knowledge possessed by educators related to the stages of child development will be able to provide intervention in preparing early intervention programs to prepare the learning environment and experience planning in accordance with the stages of early childhood development. The point is that to optimize education in early childhood, PAUD educators and parents must understand about child development.

\section{Discussion}

Early Childhood Education (PAUD) is one form of education that focuses the foundation towards growth in six aspects of development, namely: religion and morals, psycho motor, cognitive, language, social emotional and art in accordance with the uniqueness and stages of development. Early Childhood Education is very important for children's development, because through this education children can learn to interact and establish social relationships with children their age in groups. The sooner children are introduced to these things , the more beneficial they will be for their development.

Early Childhood Education (PAUD) Tunas Harapan is one of the PAUDs found in Marindal II Village of Patumbak district of Deli Serdang district which is under the auspices of the Deli Serdang district Education Office. This PAUD is one of the first PAUDs standing in marindal II village even in Patumbak subdistrict. Even PAUD Tunas Harapan is also called the oldest PAUD and includes PAUD which has a large number of students, which amounted to 105 children with a number of teachers as many as 8 people.

Early Childhood Education (PAUD) becomes so important because by following learning in PAUD will be able to help the child's development process become more optimal. PAUD not only prioritizes cognitive aspects such as reading, writing and counting (calistung) smoothly as most things happen today, but in PAUD children can learn to interact and establish social relationships with their peers in groups, help emotional and intellectual development and can form children's personalities positively. This is certainly inseparable from the involvement of parenting in the home also plays a very important role. This is in line with Elliot's affirmation in Putra et al (2013:36) that PAUD must be a period of distribution for children to mature all dimensions of their humanity, physical spiritual, mind-

body, soul of body. PAUD should never be reduced to an educational institution that focuses 
solely on exploring intellectual-cognitive content. This is in accordance with the purpose of Guidance Services (also including counseling) which is to help learners in developing their potential. With guidance carried out by teachers, children can develop their potential and children can overcome the difficulties they face.

Susanto (2016:124-125) says that parents and educators should pay attention to how to learn in early childhood is not oriented in the pursuit of achievement, but rather the orientation of children's learning. Usually the pursuit of achievement is academic in nature, such as the ability to read, write, count and play. Meanwhile, the orientation of learning and exploring the various potentials that exist in the child.

Likewise, what happens in PAUD Tunas Harapan that learning programs tend to be aimed at providing children's cognitive abilities alone, such as reading, writing and numeracy programs and academic knowledge. Whereas it should be in early childhood which is a golden time or opportunity for children to learn and this opportunity should be utilized as well as possible for the child's learning process because at this time the child has a high curiosity that is characterized by liking to try new things and asking lots of questions.

This is of course because teachers in PAUD Tunas Harapan who have diverse education, both undergraduate and high school / equivalent, teachers who are educated undergraduates but still do not meet the educational qualifications as stipulated in Permendikbud Number 137 of 2014 on teacher standards in Article 25 , namely academic qualifications of PAUD teachers:

a. have a Diploma four (D-IV) or Bachelor (S1) in early childhood education, and other education relevant to the early childhood education system, or psychology obtained from accredited study programs and;

b. have a certificate of Teacher Professional Education (PPG) PAUD from an accredited college.

- Article 26 Academic Qualifications of Companion Teachers:

a. have a Diploma four (D-IV) or Bachelor (S1) in early childhood education and other education relevant to the early childhood education system or psychology obtained from accredited study programs; or;

b. have a PGTK D-II diploma from an accredited Study Program.

- Article 27 Academic Qualifications of Young Accompanying Teachers

1) have a high school diploma and;

2) have a certificate of training/ education / PAUD courses from competent government agencies.

Based on Permendikbud Number 137 of 2014 above it can be seen that PAUD teachers in PAUD Tunas Harapan are not in accordance with the established educational qualifications. This is also of course what makes teachers as guidance teachers in PAUD Tunas Harapan can be said to be unprofessional. Teachers in addition to serving as teachers also act as mentors in helping children grow and develop. In the development of guidance 
programs should be well planned and supported with an organized curriculum. The guidance process is inseparable from the overall learning process, in other words that guidance and learning are an integrated process.

At the level of Early Childhood Education (PAUD), the function of guidance and counseling is more preventive. This is in accordance with the purpose of guidance and counseling, which is to help learners / students in order to achieve maturity and independence in their lives and carry out their developmental tasks that include personal, social, learning, career aspects as a whole and optimal.

Furthermore, it can be concluded that the function of guidance services in early childhood is more emphasized to the function of understanding and prevention functions. The function of understanding is through guidance conducted by teachers to produce a thorough understanding of various aspects that exist in children, related to the six aspects contained in the Standard level of Achievement of Child Development. Teachers must understand that the child is an individual who has a variety of characteristics that are different from each other, different advantages and disadvantages. While guidance on early childhood as a preventive function is intended to provide prevention against various possibilities, namely providing prevention against various possibilities that can be experienced by children during the development process. This possibility can be a problem related to social, emotional conditions or the ability to adapt to the environment at large. Because in early childhood is a very important period for brain growth, intelligence, personality, memory and various other aspects of development so that the inhibition of growth and development of children at this time will be able to cause inhibition of growth and development of children in the future.

Guidance should be carried out by professional experts, this is in accordance with the statement contained in Law No. 20 of 2003 on the National Education System, that educators / teachers are professionals who are tasked with planning and carrying out the learning process, conducting guidance and training, and conducting research and community service. Therefore, a PAUD teacher as a guidance teacher is required by professionals to fulfill their duties appropriately in their portion so that an individual can solve the problem very well. Professional work is supported by a certain science in depth that is only possible obtained from appropriate educational institutions so that its performance is based on the science it has that can be accounted for scientifically. Thus a teacher needs to have special abilities, abilities that are impossible for people who are not teachers. Teachers are one of the fundamental factors that determine the quality of education. From the academic qualifications possessed it is expected that teachers will be able to improve existing competencies. This is one of the shortcomings in the implementation of Early Childhood Education in PAUD Tunas Harapan, namely the lack of professional teaching teachers due to non-linear educational qualifications in addition to inadequate facilities and infrastructure. 
Based on the observations and interviews of the author with the principal and teachers at PAUD Tunas Harapan, that there are still teachers who do not understand the Standard level of Child Development Achievement. Teachers who do not understand so as not to use the Standard level of Child Development Achievement (STPPA) as a reference in designing learning activities.

Standards of Child Development Achievement Level (STPPA) which includes growth and development that can be achieved in a certain age range, which includes growth, namely weight gain and height that reflect health and nutrition conditions, while child development is an integration of the development of six aspects, namely aspects of religious and moral values, motor, cognitive, language, social emotional and artistic conditions.

Teacher education qualifications that are undergraduate but not linear plus teachers whose education only finishes high school, then are not supported by other education and training relevant to PAUD make teachers in PAUD Tunas Harapan unprofessional in carrying out learning by using various strategies and methods in teaching and designing learning and playing activities for their students.

Teachers as above should strive to improve their knowledge of the Standard level of Child Development Achievement (STPPA) obtained from trainings, workshops, seminars, both facilitated by the government and independently about the Standard level of achievement of child development so that the knowledge obtained both about strategies and teaching methods in using and developing standards. Achievement of Child Development (STPPA) can be used as a reference for teachers in designing fun activities for learners and teachers can implement them in PAUD Tunas Harapan.

A guidance teacher in PAUD should learn to understand step by step one about the stages of child development from the age of 0-6 years. Especially the stages of child development in the motor aspect, both fine and gross motor in PAUD Tunas Harapan, but due to a narrow playing page compared to the number of students 105 people can be said to be inadequate so that learning activities outside the classroom to train motor physical both fine and gross motor are still very less maximal. Learning is still more dominant in the classroom. This becomes one of the obstacles as mentioned by one of the teachers at PAUD Tunas Harapan.

The facilities and infrastructure in PAUD Tunas Harapan are inadequate and supportive so as to create a conducive environmental atmosphere. Classrooms as well as narrow play pages are less supportive for learning activities through play. Supporting facilities and infrastructure are important things that need to be considered because it will make the atmosphere of the environment conducive in the learning process in developing early childhood creativity, where children will feel safe and free to express and realize themselves, can please children, an environmental atmosphere that is in accordance with the development of children who will foster a sense of wanting to innovate, learning motivation, 
responsibility, independence, self-confidence, cooperation, social children, willingness to try and skilled.

The importance of environmental arrangements for the optimization of children's learning is also stated by Anziano et al in Susanto (2016: 128) mentioning the design of indoor and outdoor spaces and choices of materials and equipment encourages or restrict children experiences, affecting their behavior, and even their emotions". According to Anziano, spatial design both inside and outside the classroom and the selection of tools and supplies are essential to stimulate or limit students in their experiences, attitudes and emotions. In other words, that complete spatial planning and equipment can develop students' attitudes and emotions, but if the layout and equipment are minimal can limit the space of movement and attitudes and emotions of students.

Furthermore, in the implementation of the Standard of Child Development Achievement Level (STPPA) in PAUD Tunas Harapan, overall teachers have not been so understanding and implementing and making it as a reference in daily learning activities in PAUD Tunas Harapan. Learning activities are more classically performed while learning activities outside the classroom are only slight due to narrow play pages in addition to the teacher's lack of understanding of the importance of learning outside the classroom. Indeed, there are not many PAUDs that apply learning systems outside the classroom including PAUD Tunas Harapan which does not apply learning outside the classroom. Children in PAUD Tunas Harapan play outside the classroom only during recess and even without significant observation by their teachers. Teachers just watch the child so as not to fall without observing aspects of the child's development when playing. This is because they do not understand the understanding of teaching outside the classroom and do not understand the importance of teaching outside the classroom, so classical teaching methods have always been the main reference in teaching early childhood.

PAUD Tunas Harapan teacher as a guidance teacher, in general can be said to have not carried out his role to the maximum in learning activities can be seen from learning activities that are carried out not in a planned and systematic manner such as determining indicators of ability, composing concepts or materials, establishing learning themes, establishing vocabulary to be developed, determining play activities, tools and materials and determining supporting activities, adapted to the needs, characteristics of the child and local culture.

PAUD Tunas Harapan teachers do not have data from teacher observations about the achievement of child development during learning activities. Teachers should be able to measure the success of learning that has been done because the achievement of learning is a picture of the achievement of growth and development of children based on six aspects of development. Teachers at PAUD Tunas Harapan do not have documented child development achievement documented in the form of daily recordings, weekly recordings and monthly recordings and semester recordings. 
Most PAUD services are performed by educators with educational qualifications with a variety of basic abilities. Considering the educational background of early childhood educators there are still many with a high school background, while Government Regulation No.19 of 2005 requires that "Educators in early childhood education have a minimum educational academic qualification diploma four (DI V) or bachelor (S1)". Therefore, the qualifications of early childhood educators still need to be improved to meet the required demands.

The results of the researcher's interview with Siti Rahmah's mother as the Principal who said that of the eight teachers of PAUD Tunas Harapan had sent their teachers to participate in supportive training, training from the Deli Serdang district education office and independent training at their own expense. One teacher who has participated in tiered education and training (Basic Level training) for PAUD independently at his own expense is Fitri Herawati S.Pd.I's mother in addition to attending seminars on PAUD. While other teachers there are those who have never followed the trainings that support, both tiered training and other training.

The role of teachers in PAUD Tunas Harapan only performs part of his role as a guide in the development of early childhood through various aspects of development. Teachers emphasize the fulfillment of targets from the cognitive aspect, especially in terms of reading and counting smoothly in accordance with the demands of parents. Teachers have not played an overall role in guiding and towards achieving the role of PAUD Tunas Harapan teachers as mentors in optimizing the Standard of Child Development Achievement Level (STPPA) then it is necessary to develop the knowledge of teachers with education improvements specifically related to PAUD. Inappropriate academic qualifications have an impact on the ability of teachers who are not maximal in the learning process,

The point is that educational programs are largely determined by several factors including educators or teachers, because teachers are strategic factors that affect the success of the education process. Teachers who major according to their field then the lessons they teach will be able to achieve better results compared to teachers without appropriate backgrounds.

\section{CONCLUSION}

Understanding of PAUD tunas harapan teachers of Patumbak district deli serdang about standards of child development achievement level (STPPA) conceptually has not understood all aspects of early childhood development contained in the Standard of Child Development Achievement Level (STPPA). This is because some of the teachers in PAUD Tunas Harapan are educated in S1 but not in accordance with educational qualifications in accordance with teacher standards set by the government, namely permendikbud number 137 of 2014. In fact, there are still teachers who teach who finish high school which should be supported by education and training (trainings) that are relevant in supporting their 
knowledge about educating early childhood. In addition, there is a lack of teacher-teacher training activities in the development of Early Childhood education (PAUD) in order to continue to get better. Likewise, in establishing cooperation between schools and parents is still rarely done. Implimentation of Standards of Child Development Achievement Level (STPPA) in PAUD Tunas Harapan district Patumbak Deli Serdang district has not been implemented properly. Learning activities are carried out not using all aspects of development in the Standard of Child Development Achievement Level as a reference in the achievement of child development. Learning programs tend to be aimed at providing children with cognitive abilities, such as reading, writing and numeracy programs and academic knowledge. The role of guidance teachers in PAUD Tunas Harapan district of Patumbak Deli Serdang district in optimizing the Standard of Achievement Level of Child Development (STPPA), as a whole has not been maximal in carrying out his role as a teacher in guiding learners to achieve growth and development in accordance with the stage of development that covers all aspects of development as contained in the Standard of Child Development Achievement Level (STPPA).

\section{REFERENCE}

Apriyanti, H. (2017). Pemahaman Guru Pendidikan. Anak Usia Dini Terhadap Perencanaan Pembelajaran Tematik. Jurnal Obsesi, 2.

Bakar, R. A. (2012). Pendidikan Suatu Pengantar. Cipta Pustaka. Hartati, Sofia. (2017)Jurnal Ilmiah VISI PGTK PAUD dan DIKMAS - Vol. 12, No. 2, Desember Hakim, A. L. (2011). Pengaruh Pendidikan Anak Usia Dini terhadap Prestasi Belajar Siswa Kelas I Sekolah Dasar di Kabupaten dan Kota Tangerang. Jurnal Pendidikan Dan Kebudayaan, 17(1), 109. https://doi.org/10.24832/jpnk.v17i1.11

Moloeng, Lexy J, (2011)Metode Peneltian Kualitatif, Bandung: Remaja Rosdakarya Muhadjir, Noeng (1996) Metodologi Penelitian Kualitatif. Yogyakarta: Rakesarasin

Peraturan Menteri Pendidikan dan kebudayaan republik indonesia nomor 137 tahun 2014 tentang standar nasional pendidikan anak usia dini

Putra, Nusa dan Dwilestari, Ninin. (2013)Penelitian Kualitatip PAUD, Pendidikan Anak Usia Dini. Jakarta

Syafaruddin, dkk. (2011)Pendidikan Prasekolah Perspektif Pendidikan Islam dan Umum. Medan: Perdana Publishing

Sujiono, Yuliani Nurani. (2009) Konsep Dasar Pendidikan Anak Usia Dini. Jakarta: PT Indeks Susanto, A. (2018) Pendidikan Anak Usia Dini. Jakarta: PT. Bumi Aksara

Widodo. (2017) Kompetensi Guru Dalam Pengembangan Keterampilan Motorik Kasar Anak Usia Dini Berdasarkan Kualifikasi Akademik. Jurnal Ilmiah VISI PGTK PAUD dan DIKMAS - Vol. 12, No. 1, Juni

Ulwan, A. N. (2013). Pedoman Pendidikan Anak dalam Islam. CV Asy Syifa 